\title{
PHILOSOPHY, LAW AND SOCIETY (A MULTI-DISCIPLINARY APPROACH)
}

\author{
Ogugua, Paul I. \\ Department of Philosophy, Nnamdi Azikiwe University, Awka \\ E-mail address: paiykeo@yahoo.co.uk
}

Keywords: philosophy, law and society

\begin{abstract}
Philosophy does not solve problems related to other disciplines alone as Winch, P. (1958:4) believes or as others might think, there are philosophical problems too irrespective of the position of Ludwig Wittgenstein. Karl Popper (1952:129) declared:

My own view of the matter is that only as long as I have genuine philosophical problems to solve shall I continue to take an interest in philosophy. I fail to understand the attraction of a philosophy without problems.
\end{abstract}

\section{INTRODUCTION}

Philosophy, law and society are familiar concepts in the experiment we call life. These concepts are of great importance and concern to philosophers, political scientists, jurists, sociologists, etc. The frequency with which philosophy and at times law are misunderstood and misconceived, provoke concern and debate in order to see the relationship between them.

One might ask why the order in the arrangement of the concepts, why not 'law, philosophy and society' or 'society, law and philosophy'? My answer is simply, it is so arranged because we have philosophy of law; and society, that means we can apply philosophical lens and principles to these other concepts.

The unwearied think that philosophy is not relevant to the concrete realities in the society. This is not true. Philosophy is not for those with massive intellects alone, it is approachable, one only need to be disposed, prepared and disciplined. It does not parade only senseless abstract ideas; it rather deals with concrete and particular issues of life.

In the course of our exposition one will discover that philosophy does not have the meaning many attach to St. Paul's admonition that people should beware of philosophy in (Colossian 2:8). It neither means occultism nor atheism; it is rather knowledge of things through their ultimate causes.

It is purpose of this paper to espouse the concepts involved, show their relationships and argue that philosophy is particularly important in human life (society) due to its unique nature. Within the calculus of the topic are concepts such as: State, sovereignty, morality, ethics, common good, justice, etc.

\section{EXPLICATION OF CONCEPTS}

We are going to look into these concepts as much as time and space permit. They include: philosophy, law, society, justice, and common good. The search for meanings of concepts and the task of establishing connecting principles and elucidating these principles are philosophic tasks.

\section{PHILOSOPHY}

Ogugua (1994:1-2) did the job of analyzing the term philosophy from historical, theological and experiential perspectives. He (1994:6) writes:

Philosophy itself is the problem of philosophy; though it has object

like other disciplines. It defies from....ages ago a precise and concise, one generally accepted definition. 
Plato in Phaedo, called philosophy "the noblest and greatest of arts"; and described it as the "acquisition of knowledge" in Euthydemus. For Socrates, it is philosophizing on death.

Definitions of philosophy abound as there are philosophers. For Jacques Maritain (1979: ) Philosophy is

the science which by natural light of reason studies the first causes or highest principles of all things, the science of things in their first cause in so far as these belong to the natural order.

For Wellner, in support of the definition above, it is the drive of reason to seek understanding to all through going by their first principles.

Russell, B. cited in Ogugua (1994:9) states it concerns itself with logical analysis of language and the clarification of meaning of words and concepts. Wittgenstein Ludwig (1969:119) opined that it is a "battle against the bewitchment of our intelligence by means of language". By implication, it involves analysis and proper conceptualization of terms; and knowledge of grammar.

Alfred North Whitehead sees it as the "craving of reason that the facts discriminated in experience be understood." It involves the use of reason, that is ratiocination. For the short philosopher of Scottish descent, Kant, philosophy can be reduced to four questions: "what can I know?", "What ought I to do?", "What can I hope for?", and "what is man?"

John Dewey defined it from its social context and sees it as "criticism of criticism". All said and done, philosophy is essentially a reflective activity; reflecting on human experience with the aid of reason to seek out answers to some questions of fundamental significance for man in the society.

\section{LAW}

The definition of law is replete with controversies; irrespective of its appearing to be neutral, it is value-laden.

Law is a pervasive societal phenomenon; a control mechanism for social relationships in the bid to regulate human conduct. What is the nature of Law? According to Montesquieu (1952:1), "laws, in their most general signification, are the necessary relations arising from the nature of things". That shows that it signifies uniformity of operation; and as such is a measure of action. In our context (within human society), it imposes moral necessity on man. Hence, we can hold that it is an integrative societal force defining relationships. Law is this effective, because it has some characteristics namely: consistency, persistency, predictability, reciprocity and restraint, so stated Sofola, A (1994:257-266).

According to Wilson Woodrow as cited in Appadorai, A. (1978:59) law is that portion of the established thought and habit which has gained distinct and formal recognition in the shape of uniform rules backed by the authority and power of government.

Law does not just emerge with any government. It is part and parcel of the society or else why did Rousseau, J.J. (1968:82) see it as "acts of the general will,... registers of what we ourselves desire." You see it has to do with freedom. Plato (1970:31) stated that law is the reasoned thought embodied in the decrees of the state. It does not rest on the mere will of the governing power but rather, it participates in the idea of justice.

Aquinas improved on all the definitions given, he states it is an ordinance of reason for the common good, promulgated by him who has the care of the community. From these definitions we discovered that laws need be rational, is made up of rules promulgated by one in authority, disobedience to it warrants sanction. Again, that it is binding and heads towards the actualization of an ethically good social life. 


\section{SOCIETY}

Many disciplines define 'society' and definition varies with disciplines and even epochs. According to Folliet, J. (1963:10) it is "a system of relations between person or groups that keep in view a common end considered by them to be their good".

In the words of Schrag, C.C. et al (1963:583) society is "the patterned system of interaction that is observed among person or groups". That shows that the term society designates a state of human relationship or land a people bound together in a relationship, which is enduring. This already shows that the living things which thrive in group; colonies or herds with a kind of cooperation among the members and even a kind of leadership (though primitive) are called societies, yet the use of society as used in the definitions above suggest its use in a primary sense; these groups don't qualify. They are called societies in the secondary sense.

Philosophers equally defined society. In an article on 'Social life' in a book Practical $\underline{\text { Ethics}}$, it was defined as "an enduring union of a number of persons morally bound under authority to cooperate for a common good". In words of Messner, J (1949:102) society is "a unity constituted by a group of men bound together by their needs of mutual supplementation and their aptitude for it". Otite, O. (1979:42) made it clear that society is not a thing. He writes: "Society cannot be regarded as a concrete thing. Rather it is more or less a construct which serves as a heuristic device..." It is a reality though not a thing. For Maritain, J. (1951:10) society is "a concretely wholly human reality, tending to a concretely and wholly human good - the common good". According to Fagothey (1976: 247) and Higgins (1948:360), society is an enduring morally bound union which through the participation of the members go for common good. It is moot whether it is natural to man or not, here in context, I see it as being natural to man in agreement with the Aristotlean statement that man is by nature political. Politics, 1252.

\section{JUSTICE}

The concept of justice is at home in the minds of scholars and non-scholars. The whole idea of it points unequivocally to the good of the other. Though definitions differ on account of conceptual definition; there is unity of meaning. In Plato's Republic some thinkers defined it thus: For Polemarchus, it is giving a man his due; for Cephalus, it is telling the truth and paying one's debt; for Glaucon; it is a matter of convenience. Thrasymachus created fertile ground for political realists, in his definition; justice is the advantage of the stronger.

In Institutiones of Justinain, two definitions of justice were found. According to Justinain it is "justitia est constans et perpetua voluntas ius suum unicuique tribuens". This is found in Aristotle and Aquinas, it is giving to each man his due, neither more nor less. Summa Theologiae.

Kant preferred, the definition of Ulpian, a renowned jurist. He sees it as

Honeste vivare - To live honourably

Neminem laedere - To injure nobody

Ius suum cuique - To give every person

tribuere. their due.

Kant (1965:42) citing Justinain's Institutiones.

We prefer to show the significance of justice for law, by using these two last definitions to any other. Sullivan, D.J. (1957:165) states:

Justice is a virtue of the will, of man's power to choose the good as rationally apprehended - the goods with which the sense of desires are concerned.

He did expand it to incorporate the good of the other. In the same vein, Okere, T. (1984) commented: "Justice is really finding out about basic rights and duties and determining and apportioning appropriate shares".

A critical analysis will reveal the wooly nature of 'giving each one his due'. Do I give to the mad man the matchet because it is his and he demands it? Where there is a mixture of rights, equity comes in to stress on the rightness of an act, or emphasize on the spirit of the law. 
Justice is ontologically common to all that is: Dukor (1998:36) stressed The concept of justice is therefore, an ontology, an existent, an entity and above all necessary, logical and a priori proposition. Indeed, it is a conceptual, concrete and pragmatic truth.

\section{COMMON GOOD}

In a simplistic fashion, one can say it means that good that is common to all in the society. That end that is common to all, not just the (any) end that is for an individual or that is common to a group of persons. Human society has a nature and a destiny hence it has an end for it is teleological, this end for Aristotle is the good life. Every society has it own collective good, that good which is common and beneficial to all; it is common to the parts as well as the whole; from the whole it flows to the parts. Evans, J.W. et al (1965:88) holds the end of society is the good of the social body. It is the good human life of the multitude of persons, their communion in good living.

There is a correlation between a person as a social unit, social units and the idea of common good. The common good is the good that the state can legitimately ask of its citizens. For a scholar, the common good is the end for which society exists. The common good is an intermediate end, an end that is also a means toward the ultimate end of each member.

$\mathrm{He}$ continued; it is the temporal welfare of the community, taken both collectively and distributively. Evans et al (1965:89) emphasized all the more: the common good is not only a set of advantages and utilities, but also integrity of life, an end good in itself.

It could mean according to Rousseau in his Social Contract as cited by Barry Brain

The undertakings which bind us to the social body are obligatory only

because they are mutual, and they is such that in fulfilling them we cannot work for others without working for ourselves...

In the words of Benn S. et al cited in Brain Barry (1985:193) to seek the common good means to act justly. Little wonder, justice is considered the chief virtue of the State.

\section{LAW AND THE SOCIETY}

The first part of this sub-section will concern itself with revealing the role of law, and the social problems which law attempts to control; and the limitations of law in real life situation. The second part will deal with law in relation to the society, therein, we have to treat law and freedom; the state, the law and the principle of necessity.

\section{LAW IN THE SOCIETY}

\section{a. SOURCES OF LAW:}

Within this sub-section, we want to briefly comment on the sources of law. Law grows with the people, hence need rhyme with their way of life, and vision of reality. This is not always the case, as one can discover that there is a part of Nigerian law for instance which are not derived from our customs, or way of life, there are the law adopted from Britain (reviewed English law). These do not reflect the 'volkgeist' of Nigerians in the language of Roscoe Pound.

Law is usually said and agreed to have evolved from the customs of the land; it did because these customary practices have been consistent and persistent hence have won popular approval, and seen to be in vogue. Gray, J.C. (1963:281) held "custom is another of the sources of Law". Custom qualifies as a source of law because it is of immemorial origin, rational, just, long usage, certain, predictable, and has popular or common approval of the people. Religion can act as a source of law i.e. Sharia is operative in the Northern Nigeria.

'Causes' can be sources of law. Historical explanations of conditions which brought about the existence of the law. Flannery, E.H. (1965:269) pointed out, "it should be clear that the primary source of anti-Semitism stems from that which has isolated the Jew from other nations and cultures." 
Motives, both ethical and psychological can act as sources of law. For instance, the law banning importation of used cars, motorcycles, frozen food could be traced to psychological reasons during the Obasanjo regime in (2003). The Anti-corruption garb of an administration, and its desire to have a just society could be a source of law.

Law-abiding propensities of the people; evidences of law; practices as evidences of law and intentions of the parties concerned as evidence of law; and authority are sources of law. Burton Leiser (1969:53-61).

\section{b. THE ROLE OF LAW}

Irrespective of the system of government in practice, it is generally accepted that law puts in place normative rules, which bind the people with the attendant legal consequences. Law helps in defining relationships in the society and regulating human conduct. In the words of Olusola Aluko (1999:147)

Law...acts as the necessary equilibrium to stabilize and enforce the independence, impartiality and integrity of courts of law and to ensure easy accessibility. It equally stimulates social change for change is inevitable in any society.

There is need for law in order to handle this changing structure of human relationship and create enabling environment devoid of dangerous conflict. Is it not why Farrar (1977:4-6) presented law as an instrument of social control? Within the framework of law and order, he contends, law may also serve to suppress deviant behaviour.

It is the function of law as enshrined in the constitution to regulate the arms of government, hence it makes room for a responsive and responsible government. Abumere, P.I. et al (1997: 27) hold law lays down rules for succession to power and defines who has the right to exercise what kind of power in society.

I wonder if human beings being selfish and at times self-centred would have actually respected the rights of others if not that law has coercive and sanctive powers.

\section{c. LAW AND SOCIAL PROBLEMS}

Man grows, institutions in the society grow for the society itself is dynamic, hence society changes. Law itself must wear the dynamic garb inorder to fit into the society and retain its relevance.

There is a litany of social problems in the human society. Oloko Olatunde in his book Whither Nigeria? pointed out some basic problems threatening the well being of Nigeria.

Most social problems arise due to mistakes, weakness of the leaders and at time due to their evil nature and lack of concern for the people. These problems have to do with aberration in behaviours, anchored on social disorganization and disunity of social structures. Think of the level of assassination, robbery, prostitution, drug addiction, drug peddling, etc. The rate of crime has tripled in modern times. Psychopathic problems have heightened. Our society is today held siege by diseases: venereal diseases, A I Ds Acquired Immune Deficiency Syndrome, H.I.V., cancer, asthma, respiratory tract infection, etc.

What of problems which are political in nature; massive and brazen rigging of elections; marginalisation; denial of electoral victories, etc, social problems, ethnic conflicts; religious conflicts, these have taken the form of an inferno capable of consuming the society; especially the Nigerian polity.

When we emphasize negative values in the society laws though in the books are not functional. They are honoured in their breach. For instance, Nigerians are title hungry and crazy, so many of them are ready to do anything inorder to make money (not earn money) and get these titles. Aluko Olusola (1999:148) writes

There are laws put in place to check the occurrence of social problems and to punish violators, but most of these laws are rather obeyed in abeyance. 
Why? Possibly because they fail to reflect the social realities, or are made to cater for the selfish interests of a segment of the society.

\section{d. LIMITS OF LAW}

Law, although a central part of the society, pervasive social phenomenon it cannot cover every sphere of life in the society. The Marxists believe, law is an instrument in the hand of the ruling class to change the 'Status quo' in the society.

Law is not forever valid. It changes as society changes or else why judicial review reforms? It is not immutable like those of Medes and Persians, known as unchangeable.

Roscoe Pound of the sociological school of jurisprudence pointed out limitations of law in the human society as follows:

1. Law deals with facts, the question is, do we know the meaning of fact?

2. Duties like morality, gratitude cannot be legally enforced.

3. Legal rules cannot effectively restrain some kinds of injuries meted on people in the society.

4. The law cannot remedy hurt (injuries) to feelings and mental health.

5. Individuals most often though hurt (injured) are reluctant to set the legal machinery rolling. This is an obstacle to the effectiveness of the laws in the society, as these laws cannot be enforced 'in vacuo'.

Agbonifo, P.O. (1989:64-71).

\section{LAW IN RELATION TO THE SOCIETY}

\section{a. THE NEED FOR LAW IN HUMAN SOCIETY}

Law is an essential part of the state. The law binds the members of the state together. It signifies uniformity of action. It is to the State what the soul is to the body. The need for law can be traced to its very nature; it is prerequisite for order in the human society. Dennis Lloyd (1981:336) wrote "law is a central concept in human society, without it, indeed, there would be no society."

The arguments of philosophers from of old irrespective of the strands they took boil down to the relevance of law in human society. Law is a necessary and approved means of putting the instincts of man under control. It is equally clear that even in a state of innocence contrary to the position of Rousseau, or Marx (in classless society) that law is required in human society.

Curzon, L.B. (1979:28) pointed out three recurrent issues in the nature of law;

1. The existence of law means that some actions are no longer optional;

2. There are similarities between law and morality;

3. Legal system is made up of rules; this is why some jurists talk of law as a rule of action.

Not only jurists but philosophers too i.e. Murray (1963:188).

All seem to support the existence of law save the anarchists. Hadfield, J. (1965:35) stressed, a state should be ruled in accordance with its constitutions and known laws which have been passed by duly empowered authorities. It is the government that has the responsibility of executing these laws of a state. In the words of Laski, H. (1978:35) "Law is the coercive power of any state, for it is this power which is called into operation to prevent or punish infractions of the law".

Experience has shown that life will be unbearable if States do not have laws. As the society (apologies to contractualists) is natural, law too is natural to man for it aids man to pursue his end guidedly. Law has a kind of connection with freedom, morality and some other virtues.

\section{b. THE SOCIETY (STATE), LAW AND PRINCIPLE OF NECESSITY}

According to Procter, P. (1978:728) necessity is said to be "the condition of being necessary, needed or unavoidable; need." It could mean among other things getting good results from unpleasant act(s) but unavoidable state of affairs. The Oxford Dictionary presents a better meaning that suits us for our explication. It holds it to be 
Connection of end and means makes up the idea moral necessity. Connection of mental or verbal propositions make up the idea of logical necessity. Connection of causes and effects is in physical necessity.

To act under necessity means that one did an action which is inevitable, that means an action that is unavoidable, hence it has no alternative. Usually people see necessity in the light of the absolute, logical, moral, natural, conditional in the sense of conditioned, and philosophical.

Within the society, in the sphere of human action precisely only the issue of moral necessity calls for attention, of course it and physical necessity presuppose causal connection of necessity. Denial of causal necessity is never self contradictory as such the determination of common good cannot be a logical question, one is then faced with wooly nature of the reasons given by governments which they tend to see and bury under the principle of necessity. The pivotal question is, is determinism true? The governments can only be sincere if moral determinism were true. The lack of 'concern which these governments exhibit, shows that the governments (state) need(s) to operate under a higher moral law if actually their legitimacies should be sustained; it is this that will elicit political and legal obligation from the people except the government decides to force obedience out of the people i.e. military governments: dictatorial governments.

Many governments today tend to tilt towards the pole of legal positivism, as it seems to present some answers to the challenges in the operation of the machinery of the State. Most often positivists tend to subscribe to the principle of Machiavelli "the end justifies the means" which is adopted from the Thrasymacus view of justice - justice is the advantage of the stronger. "Principle of necessity" lies within this legal positivism. Seeing the problems inherent in this principle many people reacted. Karl Popper's Historicism is a way of addressing issues of this sort through history which acts as a corrective measure, probably through contacts of people. In Nigeria, Chief Richard Akinde reflected in the "Limits of the Principle of Necessity" - There is need that this principle be properly defined or else the state will continue to remain in the wood and bad and wicked leaders of men will mess up the state under its umbrella. Thomas, Jefferson in 1810 said

A strict observance of the written law is doubtless one of the high duties of a good citizen, but it is not the highest. The laws of necessity, of self preservation, of saving our country when in danger are of higher obligation.

We have to point out that this principle has no problem in itself, but in its usage. It has been misused by many governments, as what they do in its name does not reflect the common good. This doctrine is grounded on the 'inner morality' of Lon Fuller, finds anchorage too on the ground or "basic norm" of Hans Kelson. The principle requires a metaphysics to ground it, and can be seen in a meta-justificatory principle- an 'ought' proposition.

This 'ought' proposition saves not only the individuals from the hard fist of the state, but equally the states from the steel hand of international bodies (organs) moreso, in this era of globalization (tending towards one world 'State').

\section{c. LAW, FREEDOM AND MORALITY: ANY CONNECTIONS?}

Law is a measure of action in human society, it does then act as a kind of constraint on human desires, there seem to be a kind of paradox, the idea of freedom is embodied in law. Law tends towards enlarging human freedom. The truth is that where there is no law there can be no real freedom, for law creates enabling environment for the realization of freedom.

In the words of Jones, W.T. (1959:158) law help in making one “... not to be subject to the arbitrary will of another, but freely follows his own." Law and freedom are then correlative terms. For Rousseau, law is the act of the general will. He (1968:83) insisted that 
Laws are really nothing other than the conditions on which civil society exists. A people, since it is subject to laws ought to be the author of them.

Law creates and guarantees rights for the citizens. It creates privileges too but does not nominate those to be so privileged. Rousseau, J.J. (1968:82) contended: “...the law may well lay down that there shall be privileges, but may not nominate the persons who shall have those privileged"

Freedom can be divided into civil and political. The latter simply involves the rights to vote and be voted into political (public) offices. The former means rights recognized by law, and enforceable in the law courts if they are breached. According to Getell, R.G. (1973:148) "Civil liberty consists of rights and privileges which the states creates and protects for its subjects".

Law though a means of social control cannot and does not lessen man's freedom and responsibility.

Law has a relation with morality. Ogugua, P.I. (2002:3) states:

It is only in the light of this relationship, which is harmonic and conflictual, at times, that one can see law and morality as an issue for philosophical discussions.

Morality is from the word 'moral'. Moral according to the author of Philosophy and Philosophizing simply means

Principles of human behaviour in accordance with standards of right and wrong. It is concerned with human deportment, especially the distinction between good and bad or proper and improper demeanour.

There is a moral law which commands good to be done and evil avoided. This law is different from the legal rules - positive laws of nations. (Natural) Moral law flows from the order of being (man) or (society). It is a kind of anchorage for the positive laws of 'societies' or states. Baker Kenneth (1974:257) writes: "The Natural moral law can be inculcated by positive law or, so long as it allows different ways of compliance, it can be determined more precisely by customs".

This natural moral law reflects more the spirit of the law than the letters of the law. The introduction of 'equity' into legal systems tilts towards reclining on 'this spirit of the law.' Natural moral law is universal, it is an unformulated though discernable law, hence not submitted to the imperfections of human language. Peschke, H.C. (1975: 112) observed

Inasmuch as mankind, however, tries and must try to formulate the demands of natural law in human words, these formulations will frequently show inadequacies. The wording will not always be subtle enough to do justice to all borderline cases.

It is because this natural moral law is rooted in human nature that it forms matters of ethics.

Law is at the service of morality, so it is empty, groundless, porous, without morality. Morality gives law its backing. This is why nobody is under any obligation to obey unjust laws. It is the fact that law needs moral that we talk of legal ethics.

Law and morality exist in a kind of symbiosis. Lloyd et al (1992:819) cited Law as Fact to buttress our assertion above thus: "Law influences moral standards, especially by its use of force. It is the regular use of force and the propaganda associated with it that establish moral standards".

That law needs morality is a truistic statement. For the level of corruption in the state and even in judicial system is alarming and threatens the very life of the society. The illogical somersault of principles of law; and the principle of precedent 'Stare decisis' in Nigeria is case in point. Or else why did Aguda, T.A. (1992:6) hold the courts as one of the causes of the demise of the second republic in Nigeria? Corruption takes away "...wisdom from our councils, and every shadow of authority and credit from the most venerable parts of our constitution." Philosophy and Social Action, Vol. 16. (1990). 
Law without doubt needs morality if the society especially the judiciary should not be placed at risk and scattered by corruption. There is indeed an ontological nexus between law and morality, for man is a teleological being, likewise the society, and only morality (ethical discipline) will help law through its coercive and sanctive procedure to get the end of the society.

\section{PHILOSOPHY, LAW AND SOCIETY PHILOSOPHY AND LAW}

If there were no relationship between philosophy and these other concepts, we would not have philosophy of law (jurisprudence), and social and political philosophy. There is because philosophy is the study of reality 'per se'.

The application of philosophical principles to law is philosophy of law. It is that branch of philosophy connected with the intensity of human life as lived through the legal practice.

Karl Gareis (1968) stated that:

To the philosophical jurist, law is the expression of an idea. It is an expression of right and justice found rather than made by legislator or judge or text-writer.

This is represented by the natural law school of law. Philosophy is not concerned with facts, rather it is concerned with values, that means in the very strict sense, analytical and historical schools of law do not qualify as philosophy of law. According to Pizzorni, R.M. (1971:16)

Values are eternal...but they are discovered with the passage of time. Absolute values of the juridical order are values of justice. These are the proper objects of the philosophy of law.

For him, the tasks of philosophy in relation to law will be determining the universal concept of law; the foundation of law, and its value, and the standard for evaluating laws. Omoregbe, J. (1997:173) added his voice. He writes:

The philosophy of law is not the study of particular sets of laws of a given society or a given epoch, nor is it the study of legal systems, but rather the study of the universal and permanent features of law.

We can then see that there is a science of law (taken care of by the analytical and historical schools of law concerned with empirical study of law) and philosophy of law. Philosophy is of great service to law; it not only helps in analysis but equally in organization of thought and building of systems.

There is reasoning in law known as 'legal reasoning' the branches of philosophy known as logic and epistemology aid legal science in this area.

\section{PHILOSOPHY AND THE SOCIETY}

Experience has shown that many confuse philosophy with occultism, atheism or even deceit (as St. Paul in Colossians, 2:8) warned. Inspite of these misconceptions, philosophy has stood its ground doggedly for what it is, the study of reality 'qua tale', concerning itself with the good, the true and beauty. It is a reflection on human existence and experience in a critical fashion. Inshort, it is a spectacular force, which has shaped the minds of men, liberated man from ignorance, opened the gate of freedom, moulded men's character and led nations to the altar of development and civilization.

It does seem that we need at least an iota of philosophy to live in the society, to be able to think rationally, employ the canons of rational enterprise and communicate without creating confusion. For Ogugua said to use a word capable of being misunderstood, one need to define it or else one must be misunderstood. Mabel Olaolu (1999:154-155) believed that we do not have a choice, that we need philosophy. She writes: 
Our only choice is whether we define our philosophic mind by a conscious, rational, logical process of thinking or we allow our subconscious to accumulate a heap of unwarranted conclusions.

As philosophy gives critical and adequate (holistic) understanding of life, every human society needs the services of philosophy, if it will continue to exist meaningfully. Let us see the relevance of different branches of philosophy.

Logic is of practical utility, it is the science of correct reasoning, its importance is multidisciplinary. For instance, legal thinking makes use of logic and its principles; by laws of inference a doctor uses it in treatment of his patients.

Metaphysics has been misconceived as occultism, voodooism, jujuism or atheism. Some philosophers even asked for its rejection (Positivists). It is indeed of theoretical utility in human life. It is relevant as the comprehensive study of reality, hence it grounds every other branch of learning.

Epistemology has to do with theories of knowledge and not a theory of knowledge. Epistemological enterprise is rich as it is a critical examination and evaluation of human knowledge in its varied aspects or forms. This branch of knowledge raises our knowledge and level of awareness and consciousness, hence makes us mature beings on the planet-earth.

Ethics, no doubt is relevant in the society. It helps in bringing out that 'imago dei' in man as he lives with the other in the society. Ethics asks the critical question of morality, why be Moral? This could be interpreted to mean why should I be moral? Or/and why should there be a moral system in the society? Each question has answers. Ethics deals with questions of moral obligation. It is the branch of philosophy, which scrutinizes human conduct, it applies to every aspect of our life. In the words of Mabel Olaolu it is "the technology of philosophy."

\section{CONCLUSION}

Having come this far, we have to state emphatically that these concepts 'Philosophy, Law, and Society' are related. Philosophy as the mother discipline grounds law, and is equally at the service of the society.

Philosophy does not solve problems related to other disciplines alone as Winch, P. (1958:4) believes or as others might think, there are philosophical problems too irrespective of the position of Ludwig Wittgenstein. Karl Popper (1952:129) declared:

My own view of the matter is that only as long as I have genuine philosophical problems to solve shall I continue to take an interest in philosophy. I fail to understand the attraction of a philosophy without problems.

Philosophy has to grapple with the problem of human existence, law, society, change, crime, etc. By and large, philosophy has great relevance in the human society.

\section{References}

[1] Abumere, P.I. \& Edeko, S.E. (1997) Elements of Legal Methods Benin: Ehioda.

[2] Agbonifo, P.O. (1989) "The Limitations of Law as an Instrument of Social order in Society: A guide for the Third Republic in Nigeria" Conference Proceedings of the NSASA on Social Justice, National Integration and the Third Republic (OSU)

[3] Aguda, T.A. (1992) The Judicial Process and the Third Republic n.p: F. \& A Publishers. Citing cases Omoboriowo V Ajasin., Kadiya V. Lar; Nwobodo V Onoh; e.t.c.

[4] Aluko Olusola (1999) "On the Social Context of Law" in Oladele, B \& Olaolu, M. (eds.) Issues in Philosophy of Law Nigeria: Ben-el publishers.

[5] Appadorai; A. (1978) The Substance of Politics London: Oxford University Press. 
[6] Aquinas, T. Summa Theologiae 1-11, 990, art 4.

[7] Aristotle Politics

[8] Baker Kenneth (ed.) (1974) Philosophical Dictionary Washington: Gonzaga University Press.

[9] Brain Barry (1985) "Justice and the Common good" in Quinton Anthony (ed) Political Philosophy Oxford: Oxford University Press.

[10] Burton Leiser (1969) Custom, Law, and Morality N.Y: Anchor Books.

[11] Curzon, L.B. (1979) Jurisprudence Plymouth: Macdonald and Evans.

[12] Dukor, M. (1998) "Justice and the Principle of Necessity" in Dukor, M. (ed.) Philosophy and Politics-Discourse on Values and Power in Africa. Lagos: Obaroh \& Ogbinaka, Pub. Ltd.

[13] Evans, J.W. \& Ward, L.R. (1965) The Social and Political Philosophy of Jacques Maritain N.Y: Image Books.

[14] Fagothey, A. (1976) Right and Reason 6th ed. California: C.V. Mosby Co.

[15] Farrar, J. (1977) Introduction to Legal Method London: Sweet and Maxwell.

[16] Flannery, Edward H. (1965) The Anguish of the Jews N.Y: Macmillan.

[17] Folliet, J. (1963) Man in His Environment N.Y: Hawthorn Books Pub.

[18] Getell, R.G. (1973) Political Science London: Ginn Publishers Ltd.

[19] Gray, J.C. (1963) The Nature and Sources of Law (2nd ed) Boston: Beacon Pres.

[20] Hadfield, J. (1965) Basic Politics London: University of London.

[21] Higgins, T.J. (1948) Man as Man Milwaukee: The Bruce Pub. Co.

[22] Jones, W.T. (1959) Masters of Political Thought Vol. II. London: George Harnap \& Co.

[23] Justinain Institutiones, $\mathrm{n}$ 1,1,i

[24] Kant, I (1965) The Metaphysical Elements of Justice (Part 1 of The Metaphysical Morals) trans by Ladd Indinapolis: Bobs-Merril.

[25] Karl Gareis (1968) The Science of Law N.Y: Augustus M. Kelley Publishers.

[26] Lloyd and (1992) Lloyd's Introduction to Jurisprudence

[27] Freeman, M.D.A. London: ELBS \& Stevens.

[28] Laski, H.J. (1978) Introduction to Politics London: George Allen \& Unwin Pub. Ltd.

[29] Maritain, J. (1979) Introduction to Philosophy

[30] Messner, J. (1949) Social Ethics London: Herder B. Books.

[31] Monstesquieu, B. (1952) The Spirit of Laws London: William Benton Pub. Ltd.

[32] Ogugua, P. (1994) Philosohy for Beginners Osha: St. Jeromes Press.

[33] Ogugua, P.I. (2002) "Law and Morality: Historical Co-philosophical Survey" in Uduigwomen, A (ed) Sophia: An African Journal of Philosophy Nigeria: Dept of Philosophy UNICAL.

[34] Murray, M. (1963) An Introduction to Political Philosophy London: Cohen and West Ltd.

[35] Okere, J. (1984) “Justice in Nigeria" A Talk given to the Conference of major Superiors of Nigeria held at Issele-Uku, 11 Jan.

[36] Oloko Olatunde Whither Nigeria? (Printed by Times Press Apapa). 
[37] Olaolu, M. (1999) "Philosophy, Law and Society" in Oladele, B et al (eds) Issues in Philosophy of Law.

[38] Omoregbe, J. (1997) An Introduction to Philosophical Jurisprudence. Nigeria: Joja Press Ltd.

[39] Otite, O. and (1979) An Introduction to Sociological Studies Nigeria: Heinemann

[40] Ogionwo, O. Educational Books.

[41] Peschke, H.C. (1975) Christian Ethics Dublin: Goodlife, C.

[42] Pizzorni, R.M. (1971) Attuglita del Diritto Naturale? (as cited in Omoregbe, J.) Rome: Lateran University Press.

[43] Plato Republic

[44] Popper, K.R. (1952) "The Nature of Philosophical Problems and their Roots in Science" in The British Journal of Philosophy of Science, Vol. 3, no. 10.

[45] Rosseau, J.J. (1968) The Social Contract England: Penguin Book Ltd. Schrag, C.C., Larsen, O.N. (1963) Sociology 4th ed Washington: University of and Catton, W.R. Washingston

[46] Sofola, J.A. (1994) "Order and Deviance in Human Society" in Onigu, Otite (ed) Sociology: Theory and Applied Lagos: Malthouse

[47] Sullivan, D.J. (1957) Introduction to Philosophy U.S.A.: Brauce and Co.

[48] Winch, P. (1958) The Idea of a Social Science and its Relation to Philosophy London: Routledge and Kegan Paul.

[49] Wittgenstein, L. (1969) Philosophical Investigations trans. Ascombe, G.M. 